\title{
Cloud Physiognomy
}

\section{Describing the Indescribable}

We habitually think of the rain-cloud only as dark and gray; not knowing that we owe to it perhaps the fairest, though not the most dazzling of the hues of heaven. Often in our English mornings, the rain-clouds in the dawn form soft level fields, which melt imperceptibly into the blue; or when of less extent, gather into apparent bars, crossing the sheets of broader cloud above; and all these bathed throughout in an unspeakable light of pure rose-color, and purple, and amber, and blue; not shining, but misty-soft; the barred masses, when seen nearer, composed of clusters or tresses of cloud, like floss silk; looking as if each knot were a little swathe or sheaf of lighted rain. No clouds form such skies, none are so tender, various, inimitable. Turner himself never caught them.

- Ruskin ${ }^{1}$

7. Nimbus (Nb.), Rain Clouds. - A thick layer of dark clouds, without shape and with ragged edges, from which steady rain or snow usually falls. - Atlas international des nuages ${ }^{2}$

At first glance, the contrast between these two descriptions of rain clouds looks like a prototypical science versus art opposition, the art critic's effusive, simile-crammed ekphrasis versus the meteorologist's terse definition. But look again: John Ruskin was one of the great cloud observers of the nineteenth century, and his insights into the structure of cloud formations, for example the diagonal ranks of cirrocumulus clouds (fig. 1), find their echo in the illustrations included in later international cloud atlases (fig. 2). The moving spirit behind the first international cloud atlas, the Swedish meteorologist and cloud photography pioneer Hugo Hildebrandsson, agonized over finding just the right image for the quintessential nimbus cloud. Despite his firm commitment to using photographs for the

\footnotetext{
A B S T R A C T After centuries of serving as the metaphor for mutability, clouds began to be classified by genera and species in the nineteenth century, on the model of Linnaean taxonomy. In order to standardize nomenclature, cloud watchers had to learn to see in unison, recognizing cloud types as one would recognize human faces. The analogy between cloud and facial recognition runs deep: in both cases, a few salient features (that aquiline nose, those long wispy streaks) are foregrounded at the expense of a great many others. What the art of caricature is to faces, condensed description was to clouds: a few bold strokes that focused attention on the essential and screened out everything else. Cloud classification depended crucially on description by omission. REPRESENTA TiONs 135. Summer 2016 C The Regents of the University of California. ISSN 0734-6018, electronic ISSN 1533-855X, pages 45-71. All rights reserved. Direct requests for permission to photocopy or reproduce article content to the University of California Press at http:// www.ucpress.edu/journals.php?p=reprints. DOI: 10.1525/rep.2016.135.4.45.
} 
FIGURE 1 .

"Cloud-Flock," in John Ruskin, Modern Painters [1860] (Kent, 1888), 5:fig. 81.

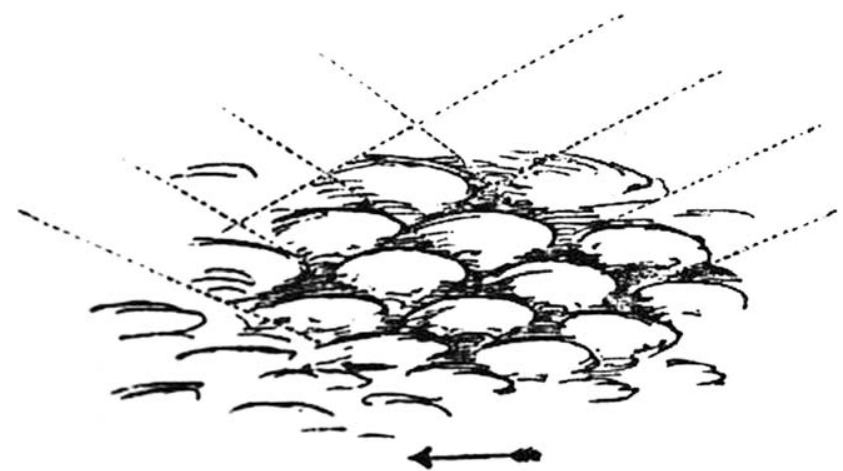

Fig. 81

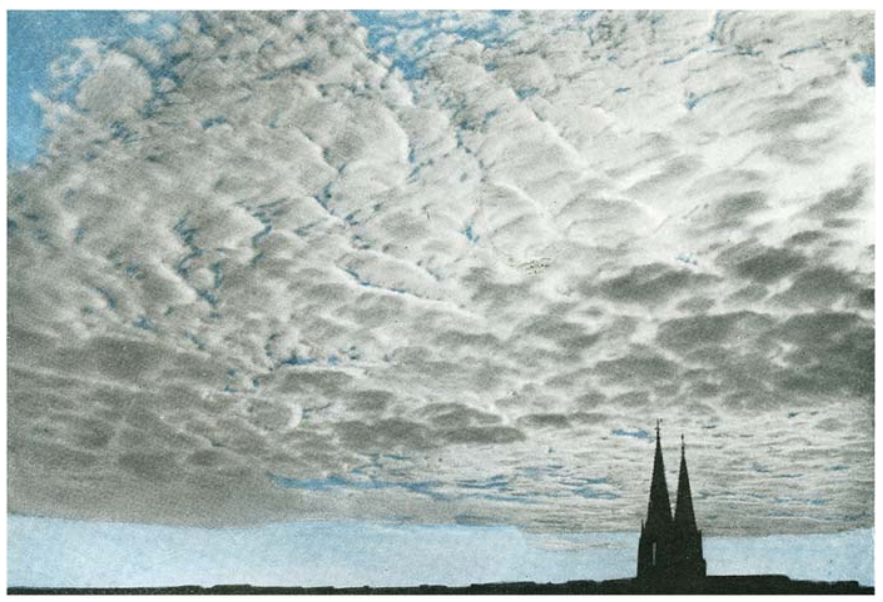

FIGURE 2 .

"Altocumulus," in International Meteorological Committee, International Atlas of Clouds and of States of the Sky

(Paris, 1930), plate 19 . 
atlas, Hildebrandsson exhorted his coeditor to trawl the museums of Paris for a suitable painting of a typical nimbus (and stratus) cloud. In the end, the atlas image of the nimbus, meant to guide observers all over the world, was a watercolor among photographs, reproduced in color at great expense and showing the ranges of tints "from blue to red" that Ruskin had conjured so rhapsodically (fig. 3). ${ }^{3}$

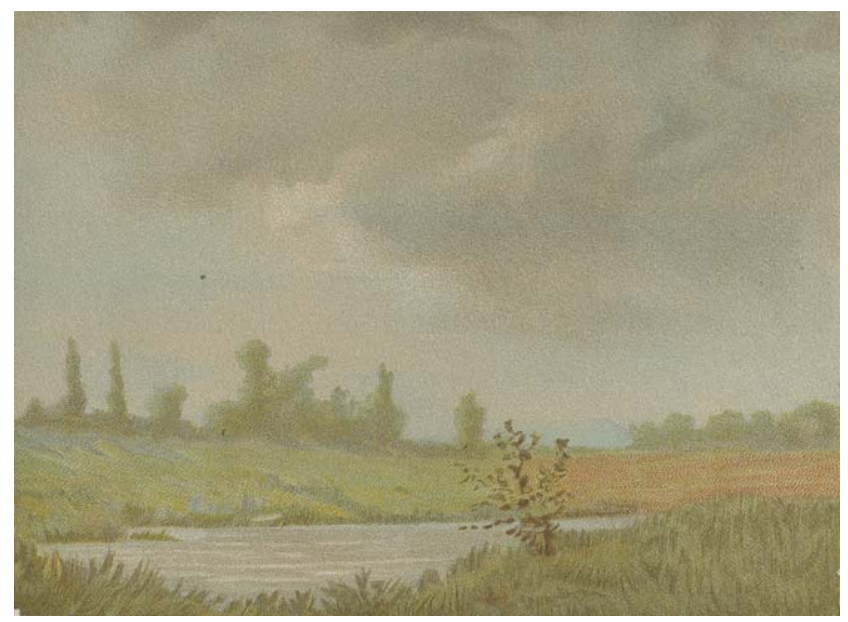

Figure 3. "Nimbus cloud," in H. Hildebrandsson, A. Riggenbach, and L. Teisserenc de Bort, eds., Atlas international des nuages. Internationaler Wolken-Atlas. International Cloud Atlas (Paris, 1896), fig. 13 of plate 7.

When it came to clouds, art and science faced similar challenges of description: how to capture almost infinite variety and variability? Both variety and variability flummox description, whether in words or in images, but not in the same way. Perform the following thought experiment: first, imagine all the species of life on earth arrayed together in their dazzling diversity, all circa ten million of them, from the Lesser Antillean iguana to the figeater beetle, from brain corals to black-capped chickadees, from mosquitoes to barley. That is variety, and clouds have it aplenty: cirrus fibratus intortus, cirrocumulus castellanus lacunosus, altostratus undulatus, and on and on. But viewed on a human time scale, it is a static variety. Evolution rarely proceeds before our very eyes. Now imagine all of these ten million-odd species constantly metamorphosing into one another and into intermediate forms-not just evolution speeded up to cinematic tempo but everything changing into everything else, all at once, not just past forms to present forms but also present to past and this present form to that other one, without regard to taxon or phylogeny. That is variability—-the vertiginous variability of clouds. 
It is not just the variety of clouds but also their fast-paced variability that eludes description: if the pace of biological evolution is too slow to be perceptible on a human timescale, that of cloud evolution is too swift for the human eye to fix, much less to capture in a net of words and images. Although the skies have been scanned and studied since the meticulous astrometeorological diaries kept for more than six centuries by ancient Babylonian scribes, and weather-watching networks sponsored by scientific societies have been trying to systematize observations since the seventeenth century, it was only at the turn of the nineteenth century that two naturalists, Jean-Baptiste Lamarck in France and Luke Howard in Britain (it is significant that both were steeped in the practices of Linnaean classification) independently and simultaneously proposed cloud classification schemes-but two quite different schemes based on different principles (figs. 4 and 5). ${ }^{4}$ For the next hundred years, cloud observers elaborated their own systems, splitting and lumping the original categories according to local weather patterns and individual proclivities. ${ }^{5}$ Is it any wonder that almost every scientific publication on cloud classification from Lamarck's and Howard's pioneer attempts around 1800 to the latest edition of the International Cloud Atlas in 1975/1987 begins with a tetchy paragraph defending the whole enterprise against skeptics who point to the notorious mutability and evanescence of their subject matter?

Clouds stretch the resources of description to their breaking point and beyond. At one extreme, they invite Ruskin's endless ekphrasis, as words multiply, never quickly enough to catch up with their protean referents. At the other, they enforce the most blinkered discipline, as observers all over the world try to coordinate eyes, words, and things into a stable, commensurable record of the face of the sky. But both extremes began, as we have seen, with concertedly systematic attempts to discover order in apparent chaos, to convert clouds from Ovidian fluidity to Linnaean fixity. I will focus here on the less obvious-and more ambitious-attempt to describe the indescribable: the international atlases of clouds, issued at irregular intervals from 1896 to 1987 and intended to anchor permanent words to impermanent things once and for all, everywhere and for everyone. The atlases taught—and still teach—cloud watchers all over the world to see (and, just as important, not see) in unison.

This achievement of collective seeing and naming was made possible by terse descriptions that focused attention on a few key details and-even more important-obscured a myriad of others. All classification depends on some degree of abstraction from the blooming, buzzing world of particulars, accentuating some significant features and muting others. A Linnaean taxonomic description of an organism is deliberately laconic: what distinguishes this species or genus from others in the larger taxon? Cloud 


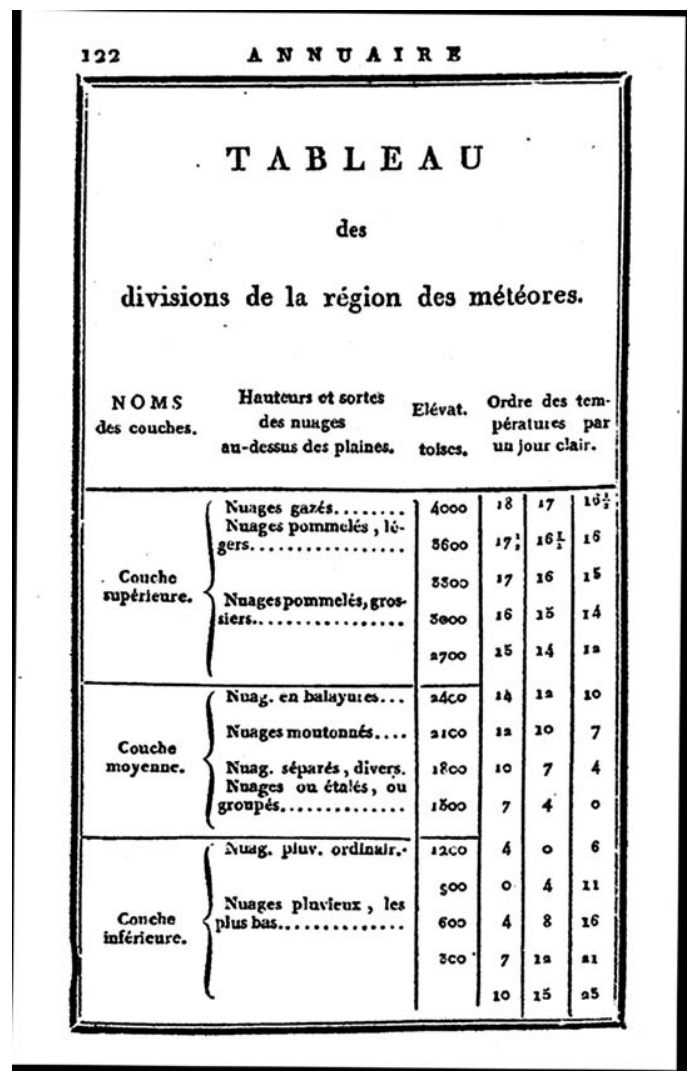

FIGURE 4. Jean-Baptiste

Lamarck, "Tableau des divisions de la région des météores," Annuaire météorologique pour l'an XI de la République Française, no. 4 (1803): 122.

FIGURE 5. "Modifications of Clouds with Symbols," in Luke Howard, On the Modifications of Clouds [1803], vol. 3 of Neudrucke von Schriften und Karten über Meteorologie und Erdmagnetismus, ed. Gustav Hellmann [1894] (Wiesbaden, 1969).

$\backslash$ Cirrus.

$\cap$ Cumulus.

- Stratus.

In Cirro-cumulus.

L Cirro-stratus.

n- Cumulo-stratus.

in- Cirro-cumulo-status, or Nimbus.

descriptions must be even more brutally reductive: they must also frame the phenomenon in both time and space, before it mutates into something else entirely. Species evolve over epochs and eons; clouds evolve over minutes and seconds. As in the case of all the organismic language that saturates cloud classification, the second usage of "evolve" in the preceding sentence 
is metaphorical, just as all talk of "genera" and "species" must be in this context. The language of cloud description is drenched in metaphor, both in Latin and in various vernaculars. The shape-shifting panorama of the sky proverbially kindles the analogical imagination: what does that cloud look like? But, as we shall see, the scientific description of clouds deliberately deadened its metaphors, first by resorting to Latin and then by reifying Latin metaphors into types. No trained observer of clouds, no matter how Latinate, should allow the mind to scamper off after the associations of castellanus (much less those of mamma and virga). Description and observation worked in tandem to make cloud classification possible by focusing, framing, and filtering.

\section{The Genera and Species of Clouds}

Figure 6 shows a cirrocumulus stratiformis lacunosus, that is, a cloud of the genus cirrocumulus, the species stratiformis, and the variety lacunosus. Although it is a photograph taken at a specific time and place-Amsterdam, at 12:20 p.m. on 19 May 1952 - it is intended, in the time-honored tradition of scientific atlases, to supply observers with a characteristic specimen of the object of inquiry. But what exactly is the object of inquiry in this case? The terminology of genus, species, and variety, familiar from organic classification schemes of plants and animals, is applied to clouds only by analogy, and by stretched analogy at that. Even the most resolute of cloud classifiers admitted that their schemes applied only "to the broad features of any sky, for no two skies are ever exactly alike any more than any two faces." ${ }^{6}$ A botanist or a zoologist might retort that all organisms, scrutinized closely enough, are also unique individuals; nonetheless, taxonomy is possible. But the predicament of the cloud classifiers is more dire: are there even such things as cloud individuals that persist over time, much less species and genera? As the most recent (1975) International World Cloud Atlas concedes, "Clouds are continuously in a process of evolution and appear, therefore, in an infinite variety of forms."7 Charles Darwin's puzzle of speciation is inverted for the cloud classifiers. Darwin had to explain why organisms are clumped in recognizable species rather than smeared out in an infinitely graduated continuum; the meteorologists must explain how the infinitely graduated continuum of clouds can be clumped into genera, species, and varieties. In the same decades during which Darwin sought to undermine the most plausible example of the ancient ontology of natural kinds, meteorologists asserted its validity for the least plausible example. Is the cirrus uncinus cloud a natural kind like the dandelion and the housecat? 


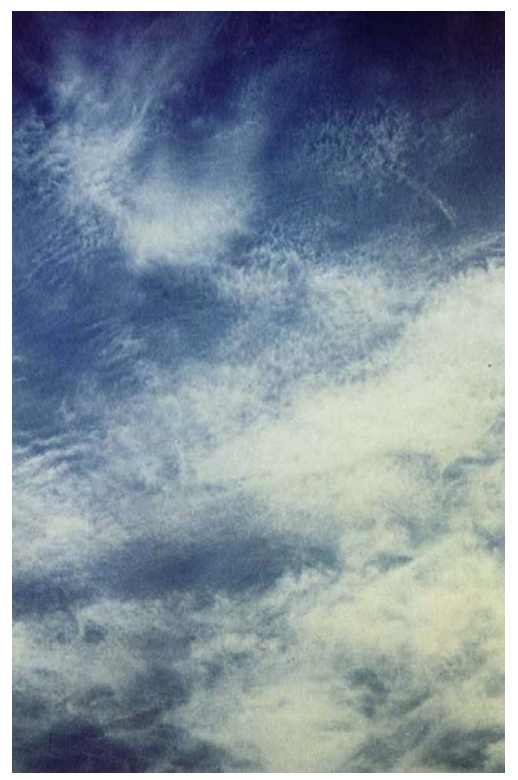

FIGURE 6. "Cirrocumulus stratiformis

lacunosus," Amsterdam, 19 May 1952, 12:20, in World Meteorological Organization, International Cloud Atlas (Geneva, 1987), 2:plate 154 .

There certainly seemed ample room for doubt on this score. The variety and mutability of clouds are legendary. Leonardo da Vinci thought they were "images made by chance," a kind of celestial Rorschach blot upon which the artist might project creative fantasies. ${ }^{8}$ Shakespeare's famous lines about clouds in Antony and Cleopatra and elsewhere play upon their suggestive mutability, the perfect metaphor for fickle affections or political instability: "Sometime we see a cloud that's dragonish / A vapour sometime like a bear or lion." ${ }^{9}$ This view was still common enough in the mid-nineteenth century for Ruskin to upbraid artists past and present for their "false" views of clouds-white paint daubed more or less at random on a blue background, as if it were impossible to be in error about forms so protean. Ruskin had nothing but contempt for the Dutch landscape painters, whose renditions of cumulus clouds had about the same relation to the clouds of nature as a "child's carving of a turnip has to the head of Apollo." ${ }^{10}$ Only William Turner, Ruskin opined, had managed to do justice to the more ethereal and evanescent cirrus cloud.

Even stay-at-home observers rooted to one spot on the globe had ample opportunity to document the ever-changing, ever-novel panorama of the clouds over their rooftops. Travelers were still more struck by the contrasts between the cloudscapes at home and those in other climes. Clouds in England and Italy displayed clear regional and seasonal differences; tropical clouds were almost as exotic as tropical flora and fauna for visitors from temperate zones. Even the same kinds of clouds looked different: "In the picture of 
a tropical sunset in $4^{\circ} \mathrm{S} .32^{\circ} \mathrm{W} \ldots$ there is a glow of light behind the dark, sharp outlined cumulus, and a beautifully lighted stripe of cirrus above, which could neither have been seen in England nor have been reproduced by an artist." 11 On the face of it, clouds seemed to be unpromising candidates for science, much less global science: too mutable to yield regularities and too local to support global generalizations. For science, description must at some point end. A world of particulars so particular that no categories can parse them and no regularity tame them defies all attempts at explanation and prediction. Clouds seemed to be plausible candidates for such irreducible particulars, endlessly describable and obdurately unclassifiable.

Yet in the last quarter of the nineteenth century, meteorologists from all over the world tried to make a science out of the shapes of clouds. Cloud classification had begun earlier in the century, with the publication of Howard's On the Modification of Clouds (1803). ${ }^{12}$ But by the 1870 s, classification systems based on Howard's original tripartite scheme of cirrus, cumulus, and stratus had splintered and ramified in the prolific fashion of the clouds themselves. Worse still, names had come unstuck from the things they were supposed to designate: a Swedish, Portuguese, and British observer might all mean different things by "cirro-cumulus"; observers beyond Europe diverged even more widely from one another. In principle, this pluralism of cloud classifications need not have been diagnosed as a crisis. If clouds were variable local phenomena, why try to impose the same classification scheme on observers in Rio de Janeiro and Uppsala? If the Deutsche Seewarte and the Portuguese navy differed regarding the number and definition of cloud rubrics in which sailors were instructed, might this not correspond to the well-known differences between the weather on northern and southern seas? In practice, however, the meteorologists reacted with alarm. In their eyes, science was international because nature was universal. A global classification of clouds was hence a precondition for and a product of international scientific collaboration.

The collaboration in question went far beyond agreement on terminology. Observers had to learn to see the sky in the same way, to divide up the continuum of cloud forms at the same points, to connect the same words to the same things. Their attention had to be sharpened for the telling detail and blunted for the idiosyncratic one. Descriptions of cloud types functioned as templates and frames for observation. This was the raison d'être for all scientific atlases, but the cloud atlas published in 1896 by the International Meteorological Committee confronted these challenges to the coordination of perception in extreme form: however much they might have differed about the choice of a characteristic anemone or kangaroo, atlas makers who documented such objects never doubted the real existence of anemones or kangaroos. But some experienced cloud observers did 
wonder about the reality of the "cirro-cumulus," and a fortiori about that of the Cirrocumulus-caudatus or the Cirrocumulus-floccus. For one thing, the bases for cloud classification diverged, even if they all preserved more or less the same rubrics: some schemes were purely formal; others corresponded to the height of the clouds (higher, middle, or lower); still others to their composition (ice crystals versus liquid water); and still others to their motions and sequence of generation from other clouds (termed "mother-clouds," to continue the biological analogy so dear to the cloud classifiers). ${ }^{13}$

In addition to their infatuation with the organismic language of genera, species, and varieties, scientific cloud observers saddled themselves with a further constraint, also with linguistic implications. They could not and did not wish to supplant lay observers. On the contrary, the observatorybased meteorologists courted mariners, farmers, and amateur observers. This meant that technical, Latinate terms had somehow to be matched to lay, vernacular terms-and in several different languages. ${ }^{14}$ The internationalism of the cloud classifiers therefore ran deeper than the usual diplomacy of large scientific congresses in metropolises like Paris and Vienna. They had to figure out whether the colloquial French "ciel pommelé" was really the same as the English "mackerel sky," and to train French and English observers to see both as a cirro-cumulus cloud (fig. 7). The creation of the International Cloud Atlas of 1896 was a remarkable exercise in collectively willed ontology, in ways of seeing, parsing, and naming nature made global by international collaboration.

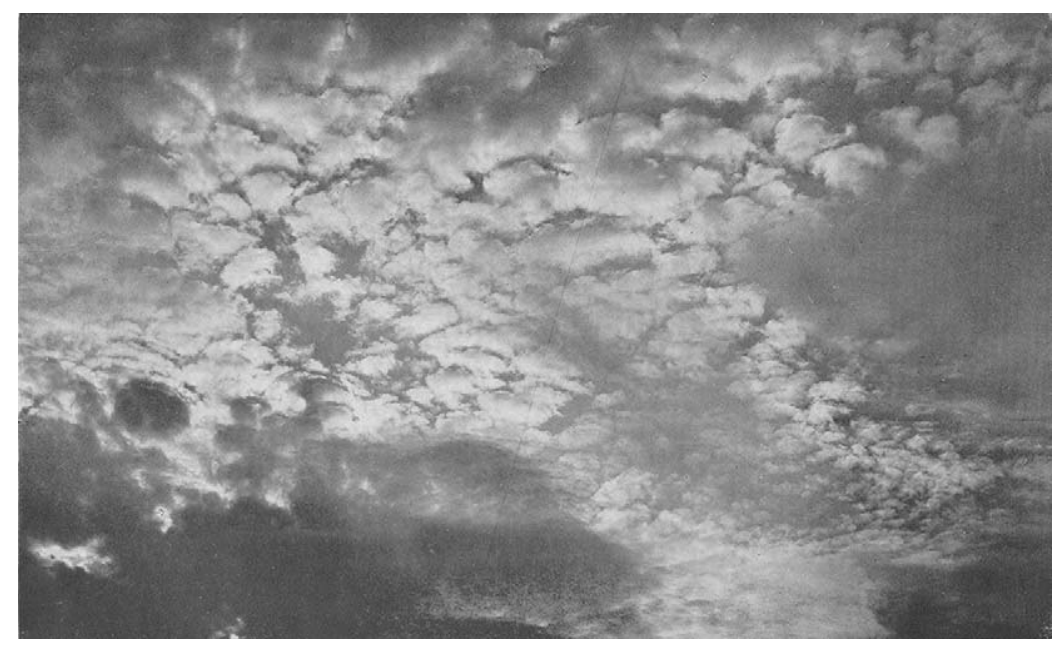

FIGURE 7. "Mackerel Sky," in Arthur W. Clayden, Cloud Studies (London, 1905), 31, plate $31,69$. 


\section{Characteristic Forms}

Clouds we have always had with us, but they became objects of scientific inquiry only in 1803, with the publication of Howard's On the Modification of Clouds. Howard took issue with the age-old view that clouds were a byword for irregularity; at least some forms or "modifications" (as he revealingly called them, drawing attention to their mutability) were distinct and widespread: the feathery cirrus; the piled-up cumulus; and the flat, spread-out stratus (fig. 8). Faithful observers of the sky, farmers and sailors, were far better versed in these features of its physiognomy than "the philosopher (who in attending only to his instruments may be said only to examine the pulse of the atmosphere)." But however well-versed these practitioners of "antient $[s i c]$ and popular meteorology" might be in the forms of clouds, Howard found the proverbs that encapsulated their knowledge about the weather to be obscure and confusing; hence, "the skill resulting from it [experience] is in a manner incommunicable." Lamarck, who had published his own cloud classification in 1802 (modified in 1805), expressed similar concerns, albeit in Cartesian terms: "Only by providing

figure 8. "Cirro-Cumulus, CirroStratus, and Cirro-Cumulo-Stratus Clouds," in Howard, On the Modifications of Clouds.

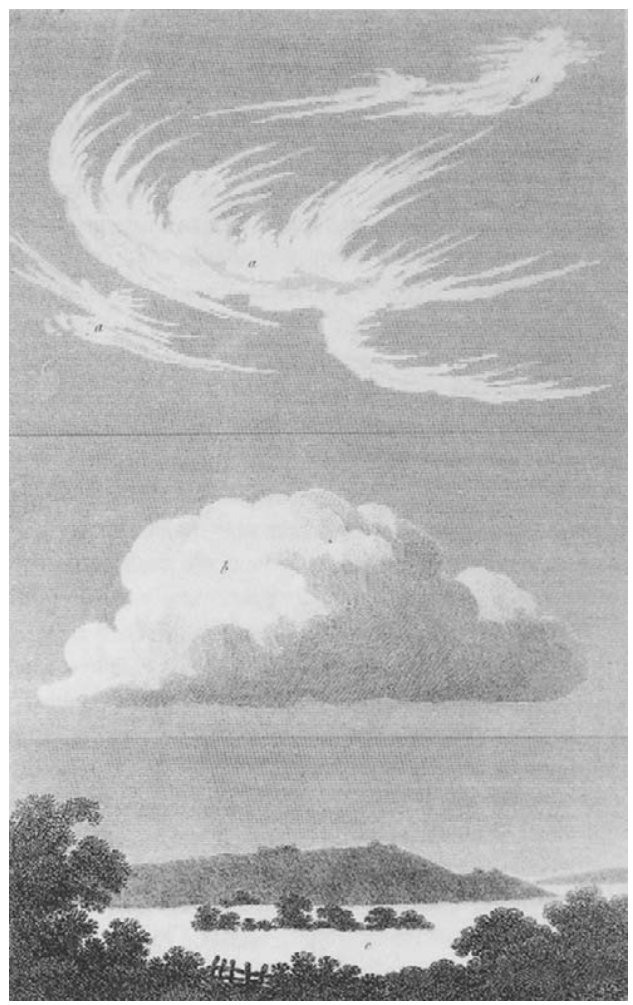


clear and distinct ideas of the objects of which we speak can humans understand and communicate their thoughts." ${ }^{15}$ Howard hoped that his "methodological nomenclature" would give popular cloud lore a voice, and one that spoke in learned Latin. He chose Latin over Greek because he thought the etymologies of the terms would be more transparent, an advantage for a nomenclature "defined by visible characters." ${ }^{16}$ In addition to the three "simple modifications," he proposed additional "intermediate" (cirrocumulus, cirro-stratus) and "compound" (cumulo-stratus, cumulo-cirrostratus or nimbus) forms, for a total of seven. Each was given a symbol, a kind of stylized hieroglyph that resembled what it signified, to streamline the recording of daily observations in weather diaries, a kind of typographical reification of the newly minted natural kinds (fig. 5). ${ }^{17}$

Although Howard's theories about how these characteristic forms were caused by electricity were controversial among other early nineteenthcentury naturalists, the forms themselves spread like wildfire. After reading Howard, naturalists and artists (for example, John Constable) suddenly saw cirrus, cumulus, and stratus clouds where they had only seen white blobs before. ${ }^{18}$ The case of the German poet and naturalist Johann Wolfgang Goethe is instructive. He had described and sketched the sky since the 1780s and '90s; a thermometer and a barometer had accompanied him on his trip to Italy. He read a German synopsis of Howard's classification scheme in 1815 and On the Modifications of Clouds in 1818. Not only did Goethe adopt Howard's nomenclature; he now also drew and attempted to see clouds as cirrus, cumulus, and stratus, recommending that other observers do the same: "If one wants to use Howard's doctrine, which distinguishes the diverse forms of clouds by naming, then one must keep the differences he points out firmly in view, and not allow oneself to be confused when certain deviant phenomena appear; one must rather practice referring these back to the principal rubrics." ${ }^{19}$ In a poem written in Howard's honor, Goethe emphasized that Howard's contribution lay in his use of names to stabilize the unstable: "Bestimmt das Unbestimmte, schränkt es ein, / Bennent es treffend! —Sei Ehre dein!" (Determine the indeterminate, rein it in / Name it aptly! —All honor to you!). As the ode to Howard suggests, the act of naming and the act of seeing fused to create well-defined forms out of ineffable, inchoate clouds that could be anything and everything. ${ }^{20}$ The precondition for description, both verbal and visual, was directed attention that focused exclusively and consistently on some features at the expense of many others. Once fixed, description in turn channeled the observer's attention. The goal was not mimesis or even vivacity, but rather truth to nature, what Ruskin called a "truth of species" in art. ${ }^{21}$ Unsurprisingly, Goethe's instructions on how to see clouds in types were quoted with approval by the editors of the first international cloud atlas. 
Despite his admiration for Howard's Adamic achievement in naming and sundering clouds, Goethe came to see the cloud classification as incomplete. By the middle decades of the nineteenth century, his name had become legion among cloud watchers. Numerous emendations and refinements were proposed; distinctions proliferated. Some systems (such as that used by the US Army Signal Corps in Washington, DC) organized the clouds into "superior" and "inferior," according to their altitude; others expanded Howard's seven rubrics to many times that number in order to capture more detail; still others, especially those devised for use at sea, contracted them to five or six. ${ }^{22}$ Whereas Goethe had been stern about the necessity of reducing all the myriad forms of clouds to Howard's seven main categories, overlooking distracting detail, British meteorologist and cloud photographer Arthur Clayden warned that there "is always a danger that the use of any system of names based on types shall lead to the neglect of everything not typical." ${ }^{3}$ The French cloud watcher André Poëy's commitment to registering fine detail extended to the point of giving the same cloud seen from different perspectives different names-a practice that drove his Hamburg colleague Wladimir Köppen fairly mad: "Are we really supposed to use five names for one and the same animal, according to whether it's seen from the front, side, back, below, or above?" ${ }^{24}$ By the 1873 meeting of the International Meteorological Congress in Vienna, the situation was judged intolerable: various observatories were invited to "publish exact representations of the form of clouds considered typical at each location." ${ }^{25}$ As the formulation of this request suggests, it was by no means a settled question as to whether the characteristic forms of clouds were the same everywhere-quite aside from the problems of reconciling the lumpers and splitters among observers.

\section{Calibration by Word and Image}

The only meteorologist to heed the Vienna call for localized cloud descriptions and images was Hugo Hildebrand Hildebrandsson, director of the observatory in Uppsala, Sweden. In 1879 he published (in French) the results of fifteen years' worth of observations at Uppsala, illustrated with photographs of forms that the Swedish observers at least considered to be typical of each of the Howardian rubrics. Hildebrandsson was not sanguine about correspondence between the Uppsala forms and those used by other observatories to classify clouds: "In perusing the bulletins of various observatories, one quickly becomes certain that confusions of this sort are produced only too often; there are perhaps only two denominations, those which refer to the typical cirrus and cumulus, that serve everywhere to designate the same species of clouds." Under the uniform names lurked 
endless quirks and nuances in classificatory practice, exacerbated by the fact that "certain clouds are proper to certain climates" and even to certain seasons of the year in the same climatic zone. ${ }^{26}$ All Hildebrandsson could do was to exhibit how observers in Uppsala attached names to things.

Or rather to photographs: the centerpiece of Hildebrandsson's report was a series of photographic plates, made under his careful supervision at considerable trouble and expense. ${ }^{27} \mathrm{He}$ considered drawings to be "too inexact" to display the intricate forms of clouds, but the photographs were explicitly meant to be typical of a class, not mechanically objective renderings of an individual cloud. Selection and enhancement were crucial to bring out key features; only a highly manipulated photographic plate could register a cloud image at all, because the brightness of the sky tended toward uniform overexposure. ${ }^{28}$ The characteristic photograph became a practice of all subsequent cloud atlases, occasionally supplemented by paintings. However judiciously selected and enhanced, the cloud photographs were, in contrast to photographs touted as objective and free of all human intervention, never allowed to speak for themselves. The coordination of word and image was essential, especially for those transitional cloud forms like the cirro-cumulus that admitted of infinite gradations and taxed the acuity even of the seasoned observer. Hildebrandsson admitted that one of his plates (number 8) could plausibly be identified as either a cirrus or a cirro-cumulus (if it could be identified as anything at all: the plates were often too dark to make out forms). Hence the importance of verbal descriptions juxtaposed to images in order to fix ideas: "Plate 8 shows a transitional form [forme de passage] between the Cirrus and the Cirro-cumulus.... Plate 9 shows those pretty forms, generally known under the name 'ciel pommelé' [that is, "fleecy sky"] or 'ciel moutonné' ["sheep sky"] in France; as 'Makerel [sic] Sky' in England; as 'Cielo empedrado' ["dappled sky”; also refers to cobblestones] in Spain." 29

The motley languages of this description reflect the complexity of international calibration among observers. Hildebrandsson was as convinced as Howard had been that lay observers were, if anything, more experienced and discerning than savants, and that fishermen and sailors sometimes surpassed even the best-equipped meteorological observatories when it came to predicting the weather from sky signs like clouds. International networks of meteorological observers had, moreover, since the late seventeenth century depended on dedicated amateurs who kept weather diaries year in, year out. ${ }^{30}$ It was by interrogating sailors in the British navy that the Reverend William Clement Ley, inspector for the British Meteorological Office, had concluded that at least four characteristic cloud forms (cirrus, cumulus, stratus, nimbus) were genuinely typical, even if not uniformly distributed all over the globe ${ }^{31}$ Hence it was important that the basic cloud classification scheme be not only clear and simple but also anchored in colloquial observation 
categories, as well as in Howard's Latin definitions and rubrics. Köppen took much the same view even for more specialized meteorological observers; he believed that the German names were at least as accurate as the Latin terms: Schleier (veil), Schäfchen (lamb), Federwolken (feather clouds). He was at pains to correlate his drawings and categories for Hamburg not only to those published by Hildebrandsson for Uppsala but also to expressions in other languages: a "bowed cirrus" in his classification, for example, corresponded to the English "mare's tail" and the German Windbäume. ${ }^{32}$

Indeed, it was probably the salience of certain cloud forms in various European vernaculars that promoted the Cirrocumulus, originally a mere intermediate form in Howard's classification, to equal status with the original three characteristic forms. When Hildebrandsson and the Scottish meteorologist Ralph Abercromby joined forces in the 1880s to correlate the major systems of cloud classification then in use, they discovered that only three designations converged: cirrus, cumulus-and cirro-cumulus. ${ }^{33}$ In Hamburg and in Hong Kong, Norway and Portugal, all observers recognized these as "true" or "typical" or "genuine" (echt) cloud forms; here word and thing meshed. In Latin, "cirro-cumulus" was no more vivid or transparent than "strato-cumulus," but whereas almost no two systems could agree on the latter, they were unanimous in picking out the former-because it had already been picked out by a completely different terminology in the vernacular. The terms that did so appealed to diverse metaphors: sheep and mackerel, cobblestones and dappling. But all had succeeded in framing perception, in carving out an evanescent but striking cloud formation as a thing worthy of its own name. When in 1896 the first International Cloud Atlas appeared in a trilingual edition, the definitions of the cirro-cumulus in French and German exceptionally added the vernacular terms: Schäfchen, Mouton. ${ }^{34}$

All of these names and descriptions referred, however, to the same image in the 1896 atlas, a plate so overexposed and darkened by time as to be visually unintelligible now. ${ }^{35}$ After the 1891 Munich meeting of the International Meteorological Committee had officially endorsed the Hildebrandsson-Abercromby cloud classification system and formed a committee to produce an atlas on that basis, the members met in Uppsala in August 1894 to choose among some three hundred images. ${ }^{36}$ These included not only photographs but also paintings and pastels; the Danish artist and cloud classifier Philip Weilbach had also been invited to participate in the committee's deliberations. Clouds were divided into ten numbered types, further subdivided by altitude and whether they portended good weather or bad. Each of the main types, as well as some secondary types, was assigned a representative image. What qualified as a representative image was a matter of collective judgment; no single person and no single medium held a monopoly. While the majority of the twenty-eight plates 
were photographs (the cirro-cumulus in plate 6 was taken in Uppsala in 1890), paintings and pastels were also included for the elusive nimbus and stratus forms. ${ }^{37}$ Hildebrandsson and Abercromby were both on record as proponents of cloud photography, because of the detail captured in that medium, but both also acknowledged limitations. Hildebrandsson insisted that color was essential. He had for this reason employed artists who worked from nature or from "good photographs" to produce paintings and chromolithographs for the 1890 cloud atlas he had published with the Hamburg meteorologists Georg Neumayer and Wladimir Köppen, who had also employed an artist. ${ }^{38}$ Here as well the choice of images had been collective; Hildebrandsson had traveled to Hamburg in 1888 expressly for this purpose and then had some of the paintings redone on Weilbach's advice. ${ }^{39}$

By coordinating their own judgments of typicality, the atlas committee hoped to make it possible to coordinate those of observers worldwide. The aim of presenting secondary as well as primary cloud forms was to "direct thereby the attention of observers to the characteristic differences between these [primary] types and the forms derived from them." ${ }^{40}$ At the same time that they selected images together in Uppsala, the atlas committee also fixed the definitions and descriptions, as well as the observing instructions: further grids for the calibration of perception, again modeled in microcosm by the collective activities of the committee itself. ${ }^{41}$ The publication of the atlas had originally been timed to coincide with a coordinated year of worldwide observation starting in May 1896, so as to have all observers start tabula rasa with the new atlas. ${ }^{42}$ Ever after, the occasion for a new edition of the atlas was not so much new knowledge about the physics of clouds or better imagesboth in constant production-but rather the exhaustion of the previous edition and the consequent fear that "the quality of the observations should degenerate and differences of interpretation reappear" if cloud watchers were no longer calibrated by the same images and descriptions. ${ }^{43}$

All scientific atlases seek to school the eye, but the 1896 International Cloud Atlas departed from precedents in significant and sometimes paradoxical ways. It transferred authority from a recognized doyen of the field-for example, a Linnaeus in botany-to a committee constituted by an international body. No doubt the members of the committee were chosen because of their scientific stature, but none of them would have acted alone: Köppen, one of the co-authors of the 1890 atlas, cautioned against any terminological decision that might interfere with the "anticipated international regulation of terminology"; he was seconded by Hildebrandsson, who probably enjoyed the greatest personal authority in cloud classification. ${ }^{44}$ The committee moreover pooled not only illustrations but also eyes: it was for the purpose of seeing collectively that they gathered in Uppsala. Finally, they attempted to turn photography, a medium at once praised and damned for its ability to capture 
a welter of individualizing details, to the ends of typicality. Precisely because cloud types were so difficult to discriminate from the infinity of possible shapes, the atlas image must confront observers with a representation as detailed as their own sky-watching experience, but nonetheless genuinely typical: a representation in every sense of the word.

\section{The Face of the Sky}

Whether or not cloud types really existed was a matter of some ontological anxiety for the meteorologists. Hildebrandsson doubted whether an international cloud atlas would ever have been undertaken had not Abercromby some years earlier sailed twice around the world to ascertain whether the main cloud types could indeed be found everywhere. Abercromby concluded that 90 percent of the world's clouds could be subsumed under the rubrics cirrus, cumulus, stratus, cirro-stratus, cirrocumulus, strato-cumulus, and nimbus. These "common forms" were not only universal but also more durable than rarer forms like festooned or udder-like clouds (mammata). But their distribution was hardly uniform: cumulus was, for example, present year-round in the tropics, but vanishingly rare in northern climates during the winter and perhaps hardly seen at all in arctic regions. Moreover, the same cloud types looked different in different climes and presaged different weather. It was proverbial in France and England that the cirro-cumulus was the harbinger of fine weather, but in Italy, "Cielo a pecorelle / Acqua a catinelle." Weather prediction remained local knowledge, even if cloud types were universal-universal, but not necessarily common. Even Hildebrandsson admitted that the carefully selected images of typical clouds were in fact rare: "Ordinarily," he warned observers, "one observes only more or less intermediary forms." 45

Abercromby believed firmly in the existence of entities, however rare, like the "true cumulus" (not to be confused with an inferior specimen with irregular lumps), but he also admitted that the physiognomy of the sky was as changeable and idiosyncratic as that of the human face. ${ }^{46}$ At just the time that Darwin and others were attempting to freeze and classify "types" of human and animal physiognomy (also with the use of characteristic photographs), the meteorologists tried to chisel out true cloud types from the blooming, buzzing confusion of the skies (fig. 9).

The physiognomists of faces enjoyed, however, a signal advantage over the physiognomists of clouds in their efforts to create an ontology of types out of evanescent chaos. "Disdain" and "terror" were emotional states and facial expressions already anchored in most European languages, like the "ciel pommelé" and "mackerel sky" and the other colloquial terms for what 


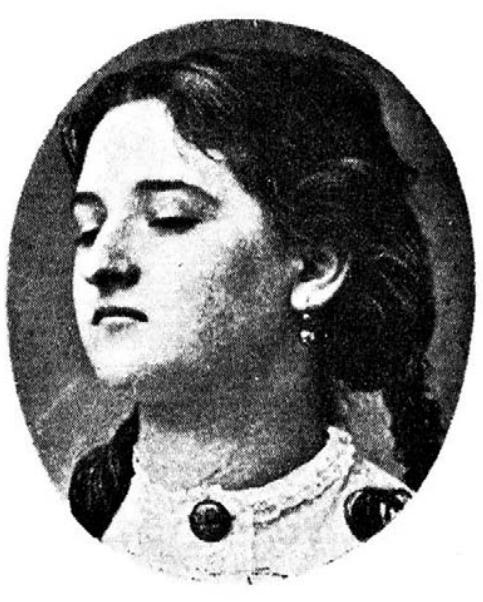

FIGURE 9. "Disdain," in Charles Darwin, The Expression of the Emotions in Man and Animals [1872], fig. 1 of plate 5 (Chicago, 1965).

meteorologists came to call the Cirrocumulus. In these languages, the continuum of experience had already been pre-parsed into types, which rang all the truer for that reason. But there were huge lacunae in the vernacular vocabulary of clouds, as the meteorologists often complained. In his Cloud Studies (1905), Clayden asserted that in "all languages there is an extraordinary scarcity of cloud names, and such as do exist are frequently applied to quite different forms by different people." 47 The otherwise dry publications of the meteorologists flower into metaphors and similes when obliged to describe especially the less familiar cloud categories. Howard had likened Cirrostratus clouds seen at a distance to "shoals of fish," though at other times more resembling "interwoven streaks like the grain of polished wood"; the same entry in the trilingual International Cloud Atlas (1896) could shift metaphors along with language. ${ }^{48}$ In French, Cumulus clouds were apostrophized as nuages en monceaux ("clouds in heaps") and similarly in German as Haufenwolken-but in English as "wool-pack clouds." 49

Meteorologists, following Howard, had originally coined technical terms, preferring new coinages in dead languages to lay expressions available in living language. The Latin terms were descriptive (at least to the learned) but deliberately unfamiliar. They were meant to startle observers into seeing clouds in a new and systematic way-as Goethe immediately realized. Latin was chosen in part for its universality (and so as not to inflame national rivalries) and in part for its distance from habitual vocabulary and the perceptions that went with them. Howard's terminology was not unlike seventeenth-century projects for universal languages: it was intended to be simultaneously transparent and strange, a pure, pre-Babel or even prelapsarian language in which words fit things like gloves. 
But after several decades of ever more divergent usage of Howard's rubrics among meteorologists, words and things had drifted apart. Although Howard's terminology had been quickly and widely adopted, it had also been adapted: who knew whether a strato-cumulus at the Uppsala Observatory was the same thing as a strato-cumulus at the Blue Hill Observatory in Massachusetts? The types wobbled with the words. Almost all observers could identify a "pure" or "true" cirrus, cumulus, or cirro-cumulus almost everywhere; everything else, however, dissolved into baroque detail. The first International Cloud Atlas of 1896 was a radical solution: the list of "types" would be drastically pruned; names, descriptions, and images would be welded to one another and thereby-it was hoped-standardize the perceptions of all observers. The entire project was grounded on the assumption that at least some types were permanent, universal, and therefore recognizable features of nature. This assumption derived covert support from language and the perceptions language crystallizes. Although the International Cloud Atlas never abandoned Howard's rubrics, by the second edition of 1932 it had resolutely emptied them of all descriptive associations and contracted the compound words to a single, seamless word (for example, "cirrocumulus" rather than "cirrocumulus"), "in order to show clearly that they have become pure symbols, whose etymology must be forgotten." 50 What had begun as a transparent, albeit estranged, language ended by becoming an intentionally opaque one. From 1803 to the latest edition, the International Cloud Atlas of 1975, language had been deployed to reveal and stabilize an ontology of cloud types.

Even the most devoted proponents of the atlas realized that fiat alone, even fiat backed up by images judiciously chosen and descriptions carefully crafted, could not will genera and species of clouds into existence. Every observer, even (or rather, especially) the most practiced, was subject to the temptations of connoisseurship-the temptation to remark, register, and (worst of all) name an enticing detail that eluded the standard descriptive template. In most observational sciences, this keen eye for minute differences is the mark of the virtuoso, an admired feat of channeled attention. But the cloud classifiers fought off this temptation. The observer, even the specialist, must learn to overlook these siren details, lest the type be obscured or lost and words once again wander away from things. Reporting on his and Abercromby's cloud classification at the 1889 Paris congress, Hildebrandsson emphasized that "typical forms [formes typiques]" of the main classificatory rubrics-the sort that qualified as atlas images-were encountered only rarely by observers in the field. Observers must not succumb to the blandishments of distinctions and details: "It is necessary, in each case, to insert in the journal the typical form which the observed form most resembles." $\mathrm{He}$ concluded by quoting Goethe on the demands Howard's nomenclature made on the observer: to see in types, not in details. ${ }^{51}$ 


\section{Conclusion:}

\section{Seeing in Types, Speaking in Tongues}

The classifiers solidified an ontology of cloud variety and variability by seeing in types and speaking in tongues. Through successive editions of the International Cloud Atlas-1896, 1910, 1932, 1956, 1975-they sought to fuse words to things by standardizing images and terms and observing protocols. Although metaphors never entirely disappeared from cloud classification-almost all the Latin names were ultimately metaphoricalmeteorological Latin, like botanical Latin, served to truncate the associations that the same words might have had in the observers' native tongues: think of the difference between Cirrus uncinus and "hooked tuft of horse hair." By the 1932 edition of the Atlas, vernacular names like "ciel pommelé" and "mackerel sky" had all but disappeared. ${ }^{52}$ Apparently, they were no longer needed to anchor perception and had been kicked away like scaffolding from a finished building.

It is tempting to conclude that it was the atlas images that did the heavy lifting in this remarkable feat of ontological creativity, and that the descriptions of the cloud genera and species were merely secondary. But in fact, if one reviews the images in successive editions of the atlas from 1896 to 1987, the images of one and the same cloud type vary considerably more than the descriptions. Let us end where we began, with the Nimbus (or the Nimbostratus, as it came to be called in later editions of the atlas). Recall figure 1, from the first edition of the atlas in 1896, and compare it with images from two subsequent editions (figs. 10 and 11). Of course there were practical reasons for changing the images: the originals deteriorated, photographic techniques improved, knowledge about cloud formation advanced. But the atlas editions were explicitly conservative, altering as little as possible, and with good reason: to change the text and images too much was to endanger the commensurability of observations past and present. What remained remarkably constant over almost a century were the terse verbal descriptions: compare those of the Nimbus (rechristened the Nimbostratus) from the 1896 and 1975 editions of the Atlas:

7. Nimbus (Nb.), Rain Clouds. - A thick layer of dark clouds, without shape and with ragged edges, from which steady rain or snow usually falls. ${ }^{53}$-Atlas international des nuages (1896), 15.

\section{Nimbostratus}

Grey cloud layer, often dark, the appearance of which is rendered diffuse by more or less continuously falling rain or snow, which in most cases reaches the ground. -International Cloud Atlas (1975), 17. 


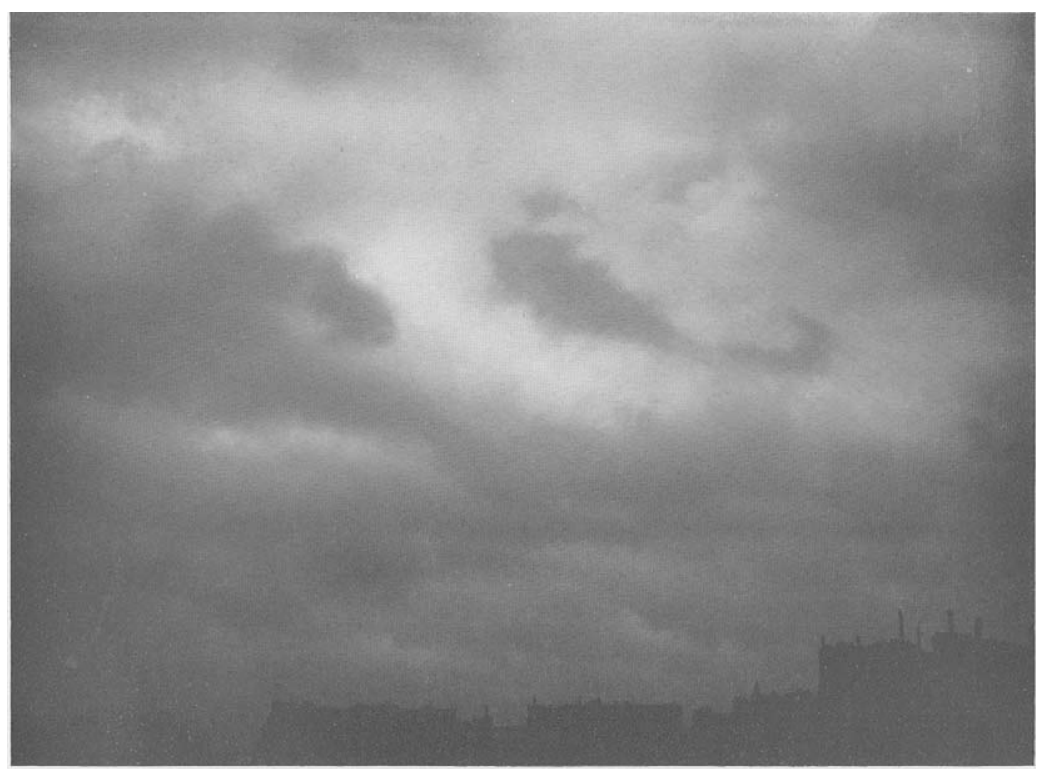

Photo O. N. M. Paris, le 30 Novembre 1925, à 13 h. 50, vers ESE, hauteur $15^{\circ}$.

FIGURE 10. “Altostratus or Nimbostratus," Paris, 30 November 1925, 13:50, in International Meteorological Committee, International Atlas of Clouds and Types of Skies (Paris, 1939), plate 12.

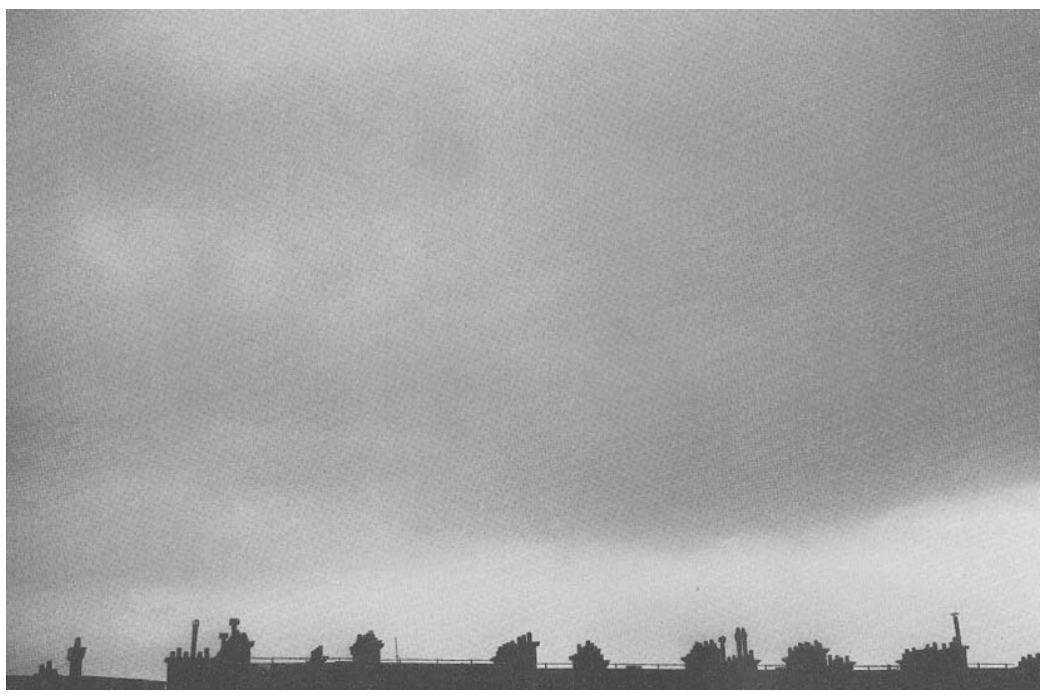

FIGURE 11. "Nimbostratus," Paris, 11 August 1949, 08:20, in World Meteorological Organization, International Cloud Atlas (Geneva, 1956), 2:plate 63. 
Given the importance of focusing observers' attention on a few telling details, it is strange that international cloud atlases were from the outset committed to photography-indeed, color photography-despite formidable technical difficulties. It was not because they fantasized about fixing reference by some automatic procedure that the cloud classifiers reached for photography. They were unapologetic about the selection of characteristic images, about coloring or retouching photographs, or supplementing, or even replacing photographs with drawings and paintings on an ad hoc basis. The 1896 International Cloud Atlas is all but unique among contemporary scientific atlases in combining photographs and paintings among its images. The word "mechanical" was not a term of praise among the cloud classifiers; how could one mechanically identify a type? They adopted photography, despite technical drawbacks, because it captured detail, not because it was allegedly free of human intervention. ${ }^{54}$ In order to train observers how to see a type in the swarm of detail presented by an actual cloud, the atlas images had to incarnate the general type in the particular individual specimen. Observers had in essence to be trained to abstract from detail by looking it square in the face. Atlas descriptions served as a pointer, highlighting taxonomically significant details-and thereby shadowing all others.

The word "face" is here used advisedly: the physiognomic analogy between the human face and clouds is an old one, and oft-repeated. When in 1663 Robert Hooke proposed a scheme for making weather observations to the Royal Society, one of the eight categories was the "face of the sky," by which Hooke mostly meant cloud configurations: "if thick after what manner $\mathrm{w}^{\text {th }}$ a thin white, long hairy racks or ... looking almost like the waves in a map or like those on the back of a mackerel." ${ }^{55}$ Howard had defended the regularity of his cloud genera by interpreting them as the visible signs of the "general causes" of variation in the atmosphere, just "as is the countenance of the state of a person's mind or body." 56 This analogy between facial physiognomy and cloud configurations stressed the underlying regularity of both phenomena; the same analogy could however also be enlisted to accent individuality and variability - like human faces, no two clouds were identical. ${ }^{57}$ But whichever way the analogy was turned, it made the recognition of cloud types into a skill as reliable as facial recognition. Clouds, the analogy implied, were genuinely physiognomic: the details that composed them gelled into a whole, just as eyes, nose, cheekbones, and mouth gelled into a face.

The physiognomic metaphor has yet to find its historian, but there's no denying its prevalence in nineteenth- and twentieth-century science-nor the work it did to solidify wobbly ontologies. The German naturalist Alexander von Humboldt wrote of "landscape physiognomies," characteristic 
combinations of flora, fauna, and topography that carved up the earth into instantly recognizable types: highlands and lowlands, tropics and tundra. Of course it was possible to dissect these landscapes into the individual organic species they sustained and their relative numbers and to correlate them with average annual temperatures by means of isotherms, a concept Humboldt invented. But the competent naturalist, just like the landscape painter, knew how to "embrace nature at a glance," panoramically and physiognomically, in order to obtain a "total impression" (Totaleindruck) ${ }^{58}$ In a completely different register, mid-twentieth-century medical researchers, astrophysicists, and particle physicists also appealed to the physiognomic judgment of the trained eye in telling apart the electroencephalograms of normal and epileptic brains or the spectra of $\mathrm{O}$ - and F-category stars. Once again, the analogies to facial recognition were explicit-sometimes disturbingly so, when different types of electroencephalograms were likened to Eskimo or Chinese faces. ${ }^{59}$

Yet even those who studied literal physiognomies, like Darwin, acknowledged the great difficulty of drawing sharp boundaries. Writing of the facial expressions associated with the emotions of "jealousy, envy, avarice, revenge, suspicion, deceit, slyness, guilt, vanity, conceit, ambition, pride, humility, \&c.," Darwin doubted "whether the greater number of the above complex states of mind are revealed by any fixed expression, sufficiently distinct to be described or delineated." ${ }^{\circ 0}$ And not all attempts to extend the physiognomic metaphor to nonfacial phenomena succeeded: the one major innovation in the cloud atlases, introduced with fanfare in the 1932 edition and completely deleted from subsequent editions, was the attempt to characterize "the state of the sky as a whole" and the "evolution of clouds," as opposed to "a dry enumeration of the genera and species of clouds in the sky." But neither a new set of special symbols nor schematic drawings accompanying the photographs was evidently enough to make the whole sky gell into a recognizable face, despite assurances that with practice, the state of the sky "will seem just as 'live' as the typical cloud forms, and it will be just as easy to identify a state of the sky as the form of a cloud." 61

Amidst all this variation, images of the typical, both drawings and photographs, helped to stabilize faces as they had clouds. Facial expressions, like cloudscapes, were mobile and fluid, one thing mutating into the next at lightning speed. Frozen expressions were the stuff of pantomime or melodrama; frozen clouds, of cardboard stage scenery or the Dutch landscapes ridiculed by Ruskin. Even the swiftest draftsman could not work quickly enough to capture the fleeting oblique angle of an eyebrow or trailing tail of a cloud. Only the photographic still could, despite 
its many other drawbacks, frame the moment of typicality before it dissolved into something else. ${ }^{62}$ The experienced reality of faces and clouds might be cinematic, but their scientific reality as objects of inquiry was photographic.

Why, one might well ask, did the cloud classifiers not emulate the botanists and illustrate their atlases with drawings that showed the genus or species? Why force the readers to detect the type in the individual? Late nineteenth-century botanists generally disdained photography just because of the clutter of detail it recorded, preferring crisp line drawings or woodcuts as truer to nature. ${ }^{63}$ The explanation of why the practices of the meteorologists and the botanists diverged, despite their shared nomenclature of genera and species, lies in the status of the types themselves. Darwinism may have shaken the metaphysics of essential organic types, but not their morphology. Botanists did not debate the synchronic distinctness and stability of genera and species, however much they might have quarreled about where to draw the boundaries among them and how to classify this or that specimen. The meteorologists enjoyed no such security with respect to clouds. Even after Abercromby and Ley had presented evidence that the main Howardian types were to be found all over the globe, albeit unevenly distributed, their fixity was still subject to question. The proliferation of classification schemes and the lack of agreement as to whether a cloud was an alto-cumulus, or a strato-cumulus, or something else altogether was not just a problem of variability among subjects; it was also understood to be a consequence of variability among objects.

The actual sky was a Heraclitean spectacle in which everything flowed. To frame a piece of this fractal fluidity and use it to instantiate a type solidified the type anew. This could only be a collective achievement, for the same reason that all languages are by their nature public. Naming was part and parcel of the perception of types-one reason why learned Latin ultimately leaned on lay vernaculars to stabilize reference and shore up the fragile ontology of types. Standardization is generally applied to things: identical manufactured goods, identical scientific instruments, identical measuring units. But it is also an achievement of persons joined in a collective. It is a prerequisite for a shared world—especially when the world in question is admitted even by cloud classifiers to be continually on the verge of chaos, and each chaos as different from the other as human faces-or as clouds. Perhaps in a gesture of humility, perhaps of hubris, the most recent edition of the International Cloud Atlas has confronted the specter of too many faces of the heavens face-on, with a name of its own: the "Chaotic Sky" (fig. 12). 


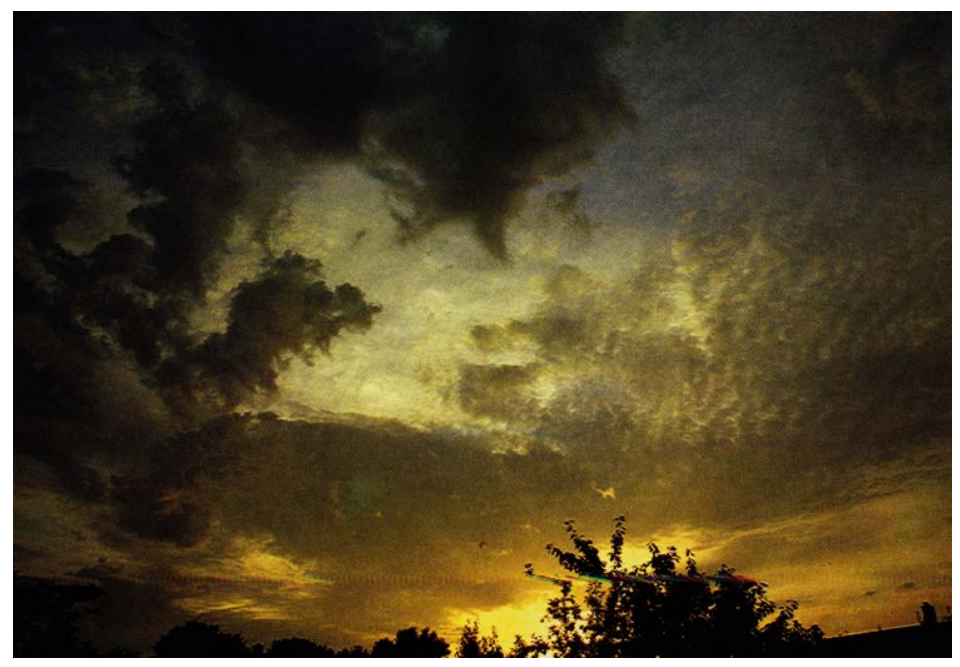

FIGURE 12. “Chaotic Sky,” Bracknell, UK, 24 June 1971, 21:15, in World Meteorological Organization, International Cloud Atlas (Geneva, 1975-87), 86.

\section{Notes}

I would like to thank the archivists at the Uppsala University Library and Bibliothèque Météo-France, Paris, for their kind assistance.

1. John Ruskin, Modern Painters [1843-88], 5 vols. (Kent, 1888), 5:§6, 140.

2. H. Hildebrandsson, A. Riggenbach, and L. Teisserenc de Bort, eds., Atlas international des nuages. Internationaler Wolken-Atlas. International Cloud Atlas (Paris, 1896), 12.

3. H. Hildebrandsson to L. Teisserenc de Bort, 13 May 1895, 6 June 1895, 4 July 1895, 13 August 1895, in Correspondence Hildebrandsson/Teisserenc de Bort, Bibliothèque MétéoFrance, Paris.

4. Jean-Baptiste Lamarck, "Sur la forme des nuages," Annuaire météorologique pour l'an X de la République Française, no. 3 (1802): 149-64; Jean-Baptiste Lamarck, "Tableau des divisions de la région des météores," Annuaire météorologique pour l'an XI de la République Francaise, no. 4 (1803): 122-54; Luke Howard, On the Modifications of Clouds [1803], vol. 3 of Neudrucke von Schriften und Karten über Meteorologie und Erdmagnetismus, ed. Gustav Hellmann [1894] (Wiesbaden, 1969). Lamarck significantly modified his initial publication in 1805: JeanBaptiste Lamarck, "Nouvelle définition des termes que j'emploie pour exprimer certaines formes des nuages qu'il importe de distinguer dans l'annotation de l'état du ciel," Annuaire météorologique pour l'an XIII de la République Française, no. 3 (1805): 112-33.

5. Louis Besson, "Aperçu historique sur la classification des nuages," Mémorial de l'Office national météorologique de France, no. 2 (1923): 5-20, offers a concise overview of these efforts. 
6. Ralph Abercromby, "On the Identity of Cloud Forms All over the World, and on the General Principles by Which Their Indications Must Be Read," Quarterly Journal of the Royal Meteorological Society 13 (1887): 141-42.

7. World Meteorological Organization, International Cloud Atlas, vol. 1, Manual on the Observation of Clouds and Other Meteors (Geneva, 1975), 11.

8. H. W. Janson, "The Image Made by Chance," in Millard Meiss, ed., De Artibus Opuscula LX: Essays in Honor of Erwin Panofsky (New York, 1961), 254-66.

9. Shakespeare, Antony and Cleopatra, 4.14.2-3; Rhodri Lewis, "Shakespeare's Clouds and the Image Made by Chance," Essays in Criticism 62 (2012): 1-24.

10. Ruskin, Modern Painters, 1:§3, 227.

11. Abercromby, "On the Identity of Cloud Forms All over the World," 140.

12. On the publication history of Howard's classification and slightly earlier attempts made by Jean-Baptiste Lamarck, see Gustav Hellmann, "Einleitung," in Howard, On the Modifications of Clouds, 7-9; on the background to Howard's work, see Richard Hamblyn, The Invention of Clouds: How an Amateur Meteorologist Forged the Language of the Skies (New York, 2001).

13. The term "mother-cloud" is first officially introduced in World Meteorological Organization, International Cloud Atlas ([Geneva], 1956), 6.

14. Lorraine Daston, "On Scientific Observation," Isis 99 (2008): 97-110.

15. Lamarck, "Nouvelle définition des termes," 113.

16. Howard, On the Modifications of Clouds, 3-4. The Latin definitions are: cirrus = tuft of horsehair; cumulus $=$ heap or pile; stratus $=$ spread out in a layer.

17. Ibid., 14.

18. On John Constable's observations and drawings to test Howard's classification, see John E. Thornes, "Kunst und Meteorologie," in Heinz Spielmann and Ortrud Westheider, eds., Wolkenbilder. Die Entdeckung des Himmels (Munich, 2004), 142-49; also Charlotte Klonk, Science and the Perception of Nature: British Landscape Art in the Late Eighteenth and Nineteenth Centuries (New Haven, 1996), 126-30. On Howard's own collaboration with the artist Edward Kennion and his indebtedness to the artistic conventions of the picturesque, see Boris Jardine, "Made Real: Artifice and Accuracy in Nineteenth-Century Scientific Illustration," Science Museum Group Journal 2 (Autumn 2014), http://journal.sciencemuseum. ac.uk/browse/issue-02/made-real/.

19. Johann Wolfgang Goethe, quoted in Andreas Beyer, "Die 'Physiognomie der Atmosphäre'. Zu Goethes Versuch, den Wolken Sinn zu verleihen," in Spielmann and Westheider, Wolkenbilder, 174. See also D. F. S. Scott, ed., Luke Howard (1772-1864): His Correspondence with Goethe and His Continental Journey of 1816 (York, 1976).

20. Goethe, quoted in Beyer, "Die 'Physiognomie der Atmosphäre'. Zu Goethes Versuch, den Wolken Sinn zu verleihen," 176.

21. "The qualities and properties which characterize man or any other animal as a species, are the perfections of his or its form of mind, almost all individual differences arising from imperfections; hence, a truth of species is the more valuable to art, because it must always be a beauty, while a truth of individuals is commonly, in some sort or way, a defect"; Ruskin, Modern Painters, 1:§1, 60-61.

22. H. Hildebrand Hildebrandsson, Rapport sur les observations internationales des nuages au Comité international météorologique (Uppsala, 1903), 3-5. H. Hildebrand Hildebrandsson, "Remarks Concerning the Nomenclature of Clouds for Ordinary Use," Quarterly Journal of the Royal Meteorological Society 13 (1887): 148-54; H. Hildebrand Hildebrandsson, "Rapport sur la classification des nuages," in Th. Moureaux, Henri Lasne, and Camille Maze (abbé), eds., Congrès Météorologique 
International, tenu à Paris du 19 au 26 septembre 1889. Procès-Verbaux Sommaires (Paris, 1889), 12-24, esp. table on 15.

23. Arthur W. Clayden, Cloud Studies (London, 1905), 8.

24. W. Köppen, "Einiges über Wolkenformen," Meteorologische Zeitschrift 4 (1887): 203.

25. Hildebrandsson, Rapport sur les observations, 5.

26. H. Hildebrand Hildebrandsson, Sur la classification des nuages employée à l'Observatoire météorologique d'Upsala (Uppsala, 1879), 1-2.

27. The photographs were made by Henri Osti; the limited edition of sixty numbered copies was financed by the Fonds de la donation Letterstedt. The copy I consulted was no. 46, from the Physik Bibliothek, Humboldt-Universität zu Berlin.

28. Hildebrandsson, "Rapport sur la classification des nuages," 23-24.

29. Hildebrandsson, Sur la classification des nuages employée à l'Observatoire météorologique d'Upsala, 8, 5.

30. Gustav Hellmann, Beiträge zur Geschichte der Meteorologie (Berlin, 1914-22); Jan Golinski, British Weather and the Climate of the Enlightenment (Chicago, 2007); Katharine Anderson, Predicting the Weather: Victorians and the Science of Meteorology (Chicago, 2005).

31. Hildebrandsson, "Rapport sur la classification des nuages," 12.

32. Köppen, "Einiges über Wolkenformen," 210.

33. Hildebrandsson, "Rapport sur la classification des nuages," 15-16. "Stratus" and "nimbus" were used as terms in all the systems surveyed, but Hildebrandsson believed that they had different referents.

34. Hildebrandsson, Riggenbach, and Teisserenc de Bort, Atlas international des nuages, 4, 14, 24.

35. Cirro-Cumulus, in ibid., plate 3, fig. 6 .

36. Bericht über die Verhandlungen der internationalen Conferenz der Repräsentanten der Meteorologischen Dienste aller Länder zu München. 26. Aug. bis 2. Sept. 1891 (Munich, 1891), 17-18. The members of the atlas committee were H. H. Hildebrandsson (Meteorological Observatory, Uppsala), Léon Teisserenc de Bort (General Secretary of the Société météorologique de France, Paris), and Abbott Lawrence Rotch (Blue Hill Observatory, Milton, Massachusetts), with the right to recruit further members as needed.

37. The nimbus was also represented by a painting (see fig. 1), despite some dissatisfaction: Riggenbach to Hildebrandsson, 18 August 1895, in Lettres à $H$. $H$. Hildebrandsson, IX.1895-96, Hanskrift-och musikemheten, A28.1.82, Uppsala University Library. On the difficulties of capturing characteristic nimbus and stratus forms with photography, see Clayden, Cloud Studies, 17. Hildebrandsson remained dissatisfied with Weilbach's stratus: "Nous avons à présent des images très acceptables à l'exception de ce misérable stratus de M. Weilbach qui est tout-à-fait impossible"; Hildebrandsson to Teisserenc de Bort, 3 December 1894, Correspondence Hildebrandsson/Teisserenc de Bort, Bibliothèque MétéoFrance, Paris.

38. H. Hildebrand Hildebrandsson, W. Köppen, and G. Neumayer, eds., Wolken Atlas-Atlas des nuages_Cloud Atlas-Moln-Atlas (Hamburg, 1890).

39. Hildebrandsson, Rapport sur les observations, 8-9.

40. Bericht über die Verhandlungen der internationalen Conferenz der Repräsentanten der Meteorologischen Dienste aller Länder zu München, 18.

41. Hildebrandsson, Riggenbach, and Teisserenc de Bort, Atlas international des nuages, 2. 
42. See the 1895-96 correspondence between Hildebrandsson and Riggenbach in Lettres à H. H. Hildebrandsson, IX.1895-96, and Correspondence Hildebrandsson/Teisserenc de Bort, Bibliothèque Météo-France, Paris, esp. Hildebrandsson's letters to Teisserenc de Bort on 19 December 1894 and 28 March 1895.

43. "Preface to 1939 Edition," in World Meteorological Organization, International Cloud Atlas ([Geneva], 1956), xi.

44. Köppen, "Einiges über Wolkenformen," 210, 257.

45. Hildebrandsson, "Rapport sur la classification des nuages," 23.

46. Abercromby, "On the Identity of Cloud Forms All over the World," 140-42.

47. Clayden, Cloud Studies, 5.

48. Howard, On the Modifications of Clouds, 9.

49. Hildebrandsson, Riggenbach, and Teisserenc de Bort, Atlas international des nuages, 5, 14, 25. The publication of the 1896 atlas was considerably delayed by the difficulty of obtaining photochromotype reproductions at an affordable price, first in Zurich and later in Paris: Riggenbach to Hildebrandsson, 19 January 1895, in Lettres à H. H. Hildebrandsson, IX.1895-96.

50. Internationales Meteorologisches Komitee, Kommission für das Studium der Wolken, Internationaler Atlas der Wolken und Himmelsansichten (Paris, 1932), vol. 1, Allgemeiner Atlas, ix.

51. Hildebrandsson, "Rapport sur la classification des nuages," 23. These instructions were repeated in the 1910 edition of the atlas; observers were instructed to double-underscore an observation in the rare event that the cloud was typical of its group: Hildebrandsson, Riggenbach, and Teisserenc de Bort, Atlas international des nuages, 9, 13.

52. In the preceding edition, they had been given, for example, for Cirro-Cumulus (Mackerel Sky) and Alto-Cumulus (Great Waves) in English, and Alto-Cumulus (Grobe Schäfchen-Wolken) and Cumulo-Nimbus (Gewitterwolken, Platzregenwolken) in German. Hildebrandsson, Riggenbach, and Teisserenc de Bort, Atlas international des nuages, 11, 21.

53. Ibid., 12.

54. On the flexibility of photography as a medium of scientific image-making in the nineteenth century, serving multiple epistemic aims, see Lorraine Daston and Peter Galison, Objectivity (New York, 2007), 126-38, and, more generally, Jennifer Tucker, Nature Exposed: Photography as Eyewitness in Victorian Science (Baltimore, 2005).

55. Robert Hooke, "For the making of a more accurate history of the changes of the weather..." (read at the Royal Society of London, 7 October 1663), Royal Society Archives, Classified Papers, vol. 20, no. 24, Royal Society, London.

56. Howard, On the Modifications of Clouds, 3.

57. Abercromby, "On the Identity of Cloud Forms All over the World," 140-42.

58. Alexander von Humboldt, Kosmos [1845-62], ed. Ottmar Ette and Oliver Lubrich (Frankfurt am Main, 2004), 232-34.

59. Daston and Galison, Objectivity, 322-46.

60. Charles Darwin, The Expression of the Emotions in Man and Animals [1872] (Chicago, 1965), 261.

61. International Meteorological Committee, International Atlas of Clouds and of States of the Sky: Abridged Edition for the Use of Observers (Paris, 1930), 24.

62. Of course, this depended crucially on the development of new emulsions that reduced exposure times: see Kelley Wilder, Photography and Science (London, 2009).

63. Alphonse de Candolle, La Phytographie (Paris, 1880), 321. 